\title{
HUMAN DIROFILARIA REPENS INFECTION IN HUNGARY: A CASE IN THE SPERMATIC CORD AND A REVIEW OF THE LITERATURE
}

\author{
S. PAMPIGLIONE ${ }^{1}$, G. ELEK $^{2}$, P. PÁLFI $^{3}$, F. VETÉSI $^{4}$ and I. VARGA ${ }^{5 *}$ \\ ${ }^{1}$ Department of Veterinary Public Health and Animal Pathology, University of Bologna, \\ Italy; ${ }^{2}$ Department of Pathology and ${ }^{3}$ Department of Urology, Central Hospital \\ of Hungarian Railways, Budapest; ${ }^{4}$ Department of Pathology and Forensic Veterinary \\ Medicine and ${ }^{5}$ Department of Parasitology and Zoology, University \\ of Veterinary Science, Budapest
}

(Received June 26, 1998; accepted August 25, 1998)

\begin{abstract}
Orchiectomy was performed in a 37-year-old Hungarian man exhibiting a swelling in his right testicle. Histology revealed a nodule attached to the spermatic cord, consisting of a granulomatous tissue around sections of a nematode. The worm was identified as Dirofilaria repens, an uncommon parasite in Hungary. As the patient had been abroad only in Italy where cases of dirofilariosis in dogs and humans are relatively frequent, it is assumed that the infection might have been acquired in that country 5 years earlier. This is the fifth case, published so far in the world, of such a localization in a human. The human cases of dirofilariosis reported in Hungary are reviewed.
\end{abstract}

Key words: Dirofilaria repens, spermatic cord, man, Hungary

Filariosis is known by most physicians as a tropical infection. In some temperate areas of the Old World, however, a peculiar filarioid worm, Dirofilaria (Nochtiella) repens (Filarioidea, Onchocercidae), a mosquito-transmitted specific parasite of the subcutaneous tissue of dogs, cats and few other carnivores can accidentally infect man. More than 400 cases are recorded in the world literature (Pampiglione et al., 1995), mostly in European Mediterranean countries and in some Asian regions. In man the worm can provoke either superficial nodules in subcutaneous or submucosal tissues, or visceral ones in the lungs or other internal localizations. In many cases the causative agent can remain unidentified due to the poor knowledge of the parasite by physicians. The diagnosis is based generally on the morphological characters of the nematode either in histological sections or of the worm in toto, when extracted from the nodule.

\footnotetext{
* Correspondence: István Varga, H-1400 Budapest, P.O. Box 2, Hungary; Tel.: (361) 342 7701; Fax.: (361) 342 6518; E-mail: ivarga@ns.univet.hu
} 
In Hungary we have recently observed a case of zoonosis that we consider useful to present on account of the scarcity of recorded cases in this country and of the peculiarity of the localization.

\section{Case presentation}

In January 1997, a 37-year-old Hungarian railwayman complained of a swelling in his right testicle. After some months a painful nodule was detected beside the testicle. Five years earlier the man had made a few-week summer trip to Northern Italy. As on clinical grounds an organized haematoma, a tumour or testicular tuberculosis was suspected, the surgeon considered necessary a radical intervention, and orchiectomy was carried out. The results of laboratory tests were unremarkable. No peripheral blood eosinophilia was noted.

\section{Materials and methods}

The testicle, $6 \times 3 \times 3 \mathrm{~cm}$, with lining envelops and a $7 \mathrm{~cm}$ long spermatic cord segment was sent for histology. A $3 \times 2 \times 2 \mathrm{~cm}$ thick grey nodule with yellow cut surface was attached to the spermatic cord. Haematoxylin-eosin (HE), PAS, Van Gieson and Masson Goldner staining procedures were carried out in sections obtained from 6 formalin-fixed, paraffin-embedded blocks.

\section{Histopathological and parasitological findings}

The testis, rete testis and most part of the funiculus were without alterations. The nodule attached to the spermatic cord showed granulomatous chronic-type tissue proliferation (Fig. 1) similar to that caused by a foreign body, with abundant eosinophilic material. In three blocks out of 6 , multiple transverse and oblique sections of a nematode were observed, showing the following morphological features: the nematode's maximum diameter was about $480 \mu \mathrm{m}$. The cuticle, 10 to $15 \mu \mathrm{m}$ thick, was formed by three layers bearing external indentations in transverse sections corresponding to sectioned external longitudinal ridges (Figs 2 and 3). These indentations were placed at distances of about 6-10 $\mu \mathrm{m}$ from each other, protruding 1-3 $\mu \mathrm{m}$. In some cases the section of the nematode came off during handling, leaving the imprint of the indentations in the surrounding tissue like a cogged wheel (Fig. 4). A thin hypoderma was recognizable in some sections. The lateral chords appeared strongly flattened, with a granular structure. The myoid fibres showed a polimyarian structure but single fibres could rarely be distinguished, 
lumped together for regressive alterations and often detached from the hypoderma. Inside the pseudocoeloma 2 to 7 tubular structures, referable to female genital tubes, could be seen, in some of which variously developed cellular elements (ovocytes) and granular material were dispersed. An intestinal tube, $10 \mu \mathrm{m}$ wide and containing granular or amorphous material, was also noted.

On the basis of the morphological features the nematode was identified as a not gravid mature female of Dirofilaria (Nochtiella) repens.

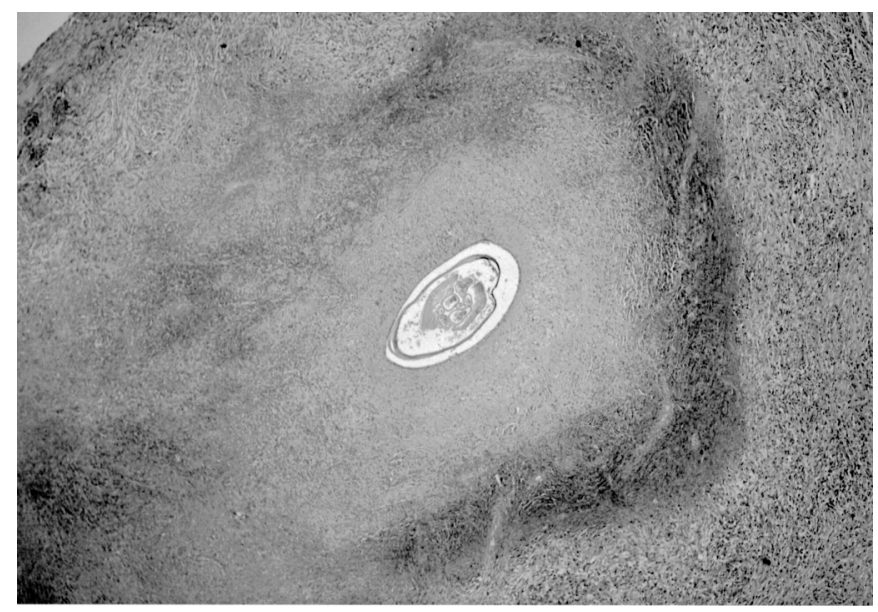

Fig. 1. Overall histological view of the nodule in the middle of which an oblique section of the nematode is visible $(\mathrm{HE}, \times 36)$

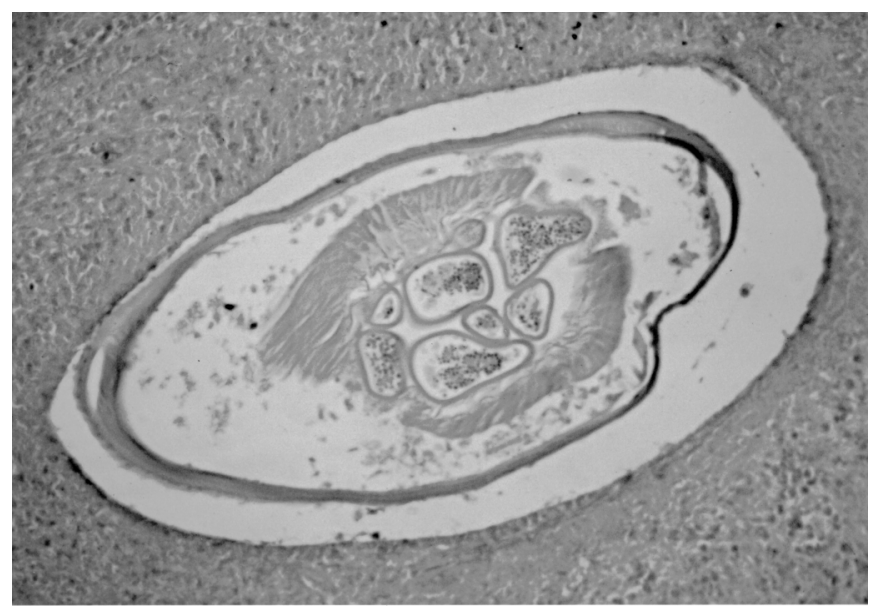

Fig. 2. A transverse section of the nematode showing six sections of the genital tube and one of the intestine. The myoid fibres are strongly altered by regressive phenomena, the lateral chords are partially disintegrated $(\mathrm{HE}, \times 150)$ 


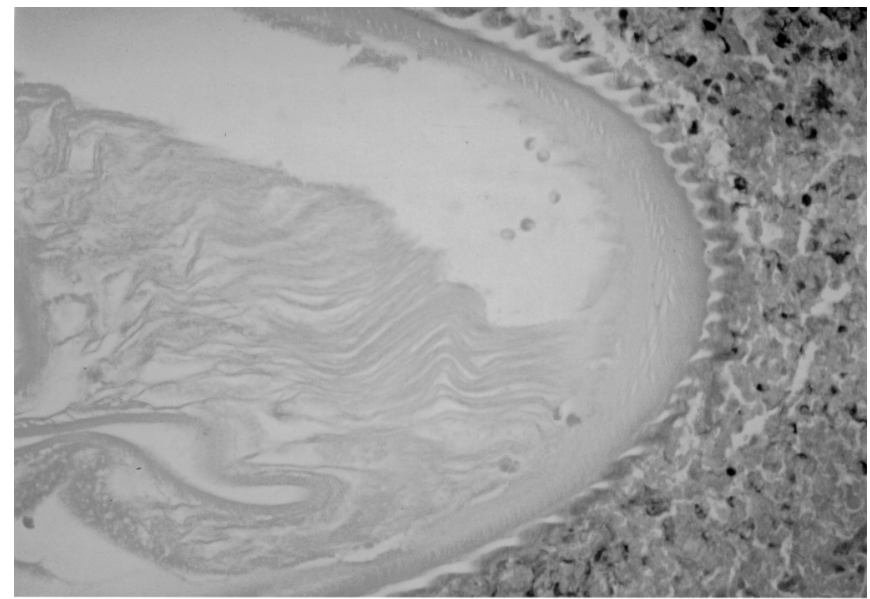

Fig. 3. Detail of the external cuticular indentations with imprint in the surrounding tissue $(\mathrm{HE}, \times 300)$

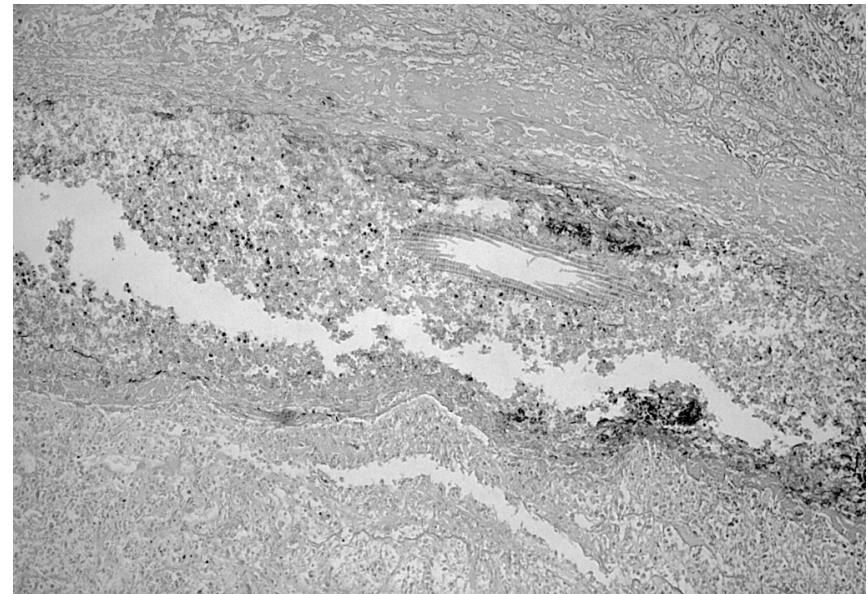

Fig. 4. In a longitudinal section of the nematode only some external cuticular ridges are visible; the remaining part of the body has been removed by the microtome cut $(\mathrm{HE}, \times 150)$

\section{Discussion}

The genus Dirofilaria includes several species in various hosts and vectors (Pampiglione et al., 1995). Differentiation of some of these species may be difficult. Diameter and cuticle structures are the most useful data in histological sections. $D$. repens differs in the shape of cuticular ridges and a larger diameter from D. ursi (Gutierrez, 1984) present in Canada, Japan and the former Soviet 
Far East with a reservoir in the brown bear. D. tenuis, a common parasite of the racoon peculiar to North America, exhibits smaller diameter than D. repens (Orihel and Beaver, 1965). D. immitis, a cosmopolitan parasite with its reservoir in the dog, can be distinguished by the absence of cuticular ridges except in the caudo-ventral portion of the male. The human cases associated with this last species are prevailingly localized in the lung.

Of the European countries, the parasite is endemic in Italy, France, Greece and the Ukraine (Pampiglione et al., 1995). In Asia the most affected countries are Sri Lanka (Dissanaike et al., 1997), Turkey, Uzbekistan and some states of the Russian Federation. In Northern European countries only sporadic cases were diagnosed, which were acquired mostly abroad, most frequently during summer travels in Mediterranean countries (Ashford et al., 1989; Settnes and Engebjerg, 1991; Jelinek et al., 1996; etc.). In the past only few human dirofilariosis cases were reported in Hungary: in 1951 Kotlán published a review of them, which we summarize here, adding a new one reported after that date.

(1) In 1880 Babes found at autopsy in St. Rochus Hospital of Budapest a nodule in the gastro-splenic ligament of an adult woman, attributed to Filaria peritonei hominis, interpreted by Desportes (1939/40) as D. conjunctivae (syn. of $D$. repens);

(2) Johan (1920, cit. by Kotlán) found a female nematode in a subcutaneous nodule in a woman, also in Budapest, diagnosed as D. magalhaesi, but later on recognized by Kotlán (1951) as belonging to the D. conjunctivae group;

(3) Anda (1941) extracted a nematode from a nodule in the temporal region of a woman, diagnosed as Onchocerca volvulus but recognised afterwards by Makara and Mihályi (cit. by Kotlán 1951) as D. conjunctivae;

(4) Makara and Mihályi (1943) in their textbook on "Insects and Diseases" report a case observed in a man in Debrecen, diagnosed as being due to $D$. immitis, but probably associated with $D$. repens;

(5) Köhegyi (1951) (cit. by Kotlán, 1951) found a nematode in a subcutaneous nodule in the temporal region of a patient, which parasite was diagnosed as $D$. repens by Kotlán (1951);

(6) Németh and Kugler (1968) extracted a specimen of D. repens localized under the conjunctiva of a man aged 21, in the Semmelweis Hospital in Budapest.

None of these reported cases was surely indigenous, due to the fact that no research was done on the possible movements abroad of the patients or no sufficient morphological details of the nematode were reported by the authors. It is also possible that $D$. repens does not exist at all in Hungary. In fact, no cases seem to be reported in dogs in this country: as communicated by F. Vetési (personal communication, 1998), no canine case was found out of ca. 35,000 dogs' 
autopsies performed since 1958 . Only a single hint is available about a suspected D. repens infection in a dog in Hungary, as reported in 1997 by Zahler et al.

Our human case was probably acquired in Italy. It is possible that the nematode survives within the host for a long time: Addario (1885) observed a case in which infection had taken place two years before, while Gardiner et al. (1978) reported a case dating back eight years. In the case reported here, the regressive alterations of the myoid fibres indicate that the nematode died some weeks or months before the extraction of the nodule.

The localization in the genital organs in man is relatively rare in the world literature: four cases have been reported in the epididymis (Bolgan et al., 1985; Marty et al., 1992; Auer et al., 1997; Messina et al., 1998), 18 in the thickness of the scrotum (Miracco et al., 1987; Kassar et al., 1990; Pampiglione et al., 1982, 1994, 1996; Nozais and Huerre, 1995; Dissanaike et al., 1997), four on the penis (Bonu and Zina, 1972; Dissanaike et al., 1997), one at the level of the testis (Miroshnikov et al., 1991), and four in the spermatic cord (Pampiglione et al., 1991, 1997; Dissanaike et al., 1997). The present one is the fifth with this last localization.

\section{Acknowledgements}

Thanks are due to Dr. K. Bogáncs for her help in preparing the manuscript. The authors thank Richard Suswillo (Oxford University) for preliminary identification of the worm. This study was partially supported by a grant from the Italian Ministry of the University and Scientific and Technological Research (MURST).

\section{References}

Addario, C. (1885): Su di un nematode dell' occhio umano. Ann. Ottalmol. 14, 135-147.

Anda, T. (1941): The first case of onchocercosis in Hungary (in Hungarian). Orvosi Hetilap 25, 331-333.

Ashford, R. W., Dowse, J. A., Rogers, W. N. and Powell, D. E. B. (1989): Dirofilarias of the breast. Lancet 27, 1198.

Auer, H., Weinkamer, M., Bsteh, A., Schmayler, C., Dietze, O., Kunit, G. and Aspöck, H. (1997): Ein seltener Fall einer Dirofilaria repens infestation des Nebenhodens. Mitt. Österr. Ges. Tropenmed. Parasitol. 19, 53-58.

Babes, V. (1880): Über einen in menschlichen Peritonäum gefunden Nematoden. Arch. f. Anat. u. Physiol. u. Klin. Med. Herausg. von R. Wirchow, 81, 158-165.

Bolgan, A., Cassaro, E. and Turchetto, M. (1985): Due casi di Dirofilaria negli annessi genitali maschili. G. Ven. Sci. Med. Venezia 36, 151-153.

Bonu, G. and Zina, G. (1972): Une rare affection chez l'homme: le granulome sous-cutané par Dirofilaria. Bull. Soc. franc. Dermatol. Syphil. 79, 248-250.

Desportes, C. (1939-40): Filaria conjunctivae Addario 1885, parasite accidentel de 1'homme, est un Dirofilaria. Ann. Parasitol. hum. comp. 17, 380-404, 515-532. 
Dissanaike, A. S., Abeyewickreme, W., Wijesundera, M. De S., Weerasooriya, M. and Ismail, M. M. (1997): Human infection caused by Dirofilaria (Nochtiella) repens in Sri Lanka. Parassitologia 39, 375-382.

Gardiner, C. H., Oberdorfer, C. E., Reyes, I. E. and Pinkus, W. H. (1978): Infection of man by Dirofilaria repens. Am. J. Trop. Med. Hyg. 27, 1279-1281.

Gutierrez, Y. (1984): Diagnostic features of zoonotic filariae in tissue sections. Human Pathol. 15, 414-425.

Jelinek, T., Schulte-Hillen, J. and Löscher, T. (1996): Human Dirofilariasis. Intern. J. Dermatol. 35, 872-875.

Kassar, L., Kchir, N., Boubaker, S., Haouet, S., Bouratbine, A., Chatti, S. and Zitouna, M. M. (1990): Un cas de Dirofilariose sous-cutanée en Tunisie. Bull. Soc. Pathol. Ex. 83, 517-520.

Kotlán, A. (1951): On a new case of human filariidosis in Hungary. Acta Vet. Acad. Sci. Hung. 1, 69-79.

Makara, Gy. and Mihályi, F. (1943): Insects and Diseases (in Hungarian). Magyar Orvosi Könyvkiadó Társulat, Budapest, p. 394.

Marty, P., Gari-Toussant, M., Le Fichoux, Y., Valla, I. S., Landragin, D. and Bain, O. (1992): Dirofilariose épididymaire simulant une torsion testiculaire chez un adolescent. Presse méd. 21, 1872-1873.

Messina, E., Doria, R., Buffini, G., Farese, A., Parenti, M. and Smorfa, A. (1998): Dirofilariosi genitale da Dirofilaria (Nochtiella) repens: Caso clinico. Atti Congr. Naz. Soc. Med. Trop., Bardolino, May 7-9, 1998.

Miracco, C., Santopietro, R. and Vindigni, C. (1987): Dirofilariasi scrotale. Riv. Parassitol. 44, 497-499.

Miroshnikov, V. P., Bakurov, E. D., Sapach, V. K., Artamonova, A. A. and Khlebnikova, O. S. (1991): Localization of Dirofilaria in man (in Russian). Khirurgyia 7, 127-128.

Németh, B. and Kugler, S. (1968): Ophthalmo-filariasis (in Hungarian). Orvosi Hetilap 109, 195-197.

Nozais, J. P. and Huerre, M. (1995): Un cas de dirofilariose du scrotum en provenance du Languedoc. Bull. Soc. Pathol. Ex. 88, 101-102.

Orihel, Th. and Beaver, P. C. (1965): Morphology and relationship of Dirofilaria tenuis and D. conjunctivae. Am. J. trop. Med. Hyg. 14, 1030-1043.

Pampiglione, S., Arlotta, M. R., Carla, T. G., D'Ambrosio, E., Filotico, R., Primiceri, O. and Vitrugno, M. (1994): La Dirofilariasi umana nel Sud d'Italia. I: Regione Puglia. Pathologica 86, 528-532.

Pampiglione, S., Canestri Trotti, G. and Rivasi, F. (1995): Human dirofilariasis due to Dirofilaria (Nochtiella) repens: A review of world literature. Parassitologia 37, 149-193.

Pampiglione, S., Canestri Trotti, G., Rivasi, F. and Vakalis, N. (1996): Human dirofilariasis in Greece: a review of reported cases and a description of a new, subcutaneous case. Ann. trop. Med. Parasitol. 90, 319-328.

Pampiglione, S., Franco, E. and Canestri Trotti, G. (1982): Human subcutaneous dirofilariasis. I. Two new cases in Venice. Identification of the causal agent as Dirofilaria repens Railliet \& Henry 1911. Parassitologia 26, 155-165.

Pampiglione, S., Montevecchi, R., Lorenzini, P. and Puccetti, M. (1997): Dirofilaria (Nochtiella) repens dans le cordon spermatique: un nouveau cas humain en Italie. Bull. Soc. Pathol. Ex. 90, 22-24

Pampiglione, S., Vagliani, G. and Milani, M. (1991): Dirofilariasi umana in Italia: localizzazione insolita nel funicolo spermatico. Progr. med. 47, 97-100.

Settnes, O. P. and Engebjerg, E. (1991): Human subcutaneous dirofilariasis caused by Dirofilaria repens. APMIS 99, 364-370.

Zahler, M., Glaser, B. and Gothe, R. (1997): Eingeschleppte Parasiten bei Hunden: Dirofilaria repens und Dipetalonema reconditum. Tierärztl. Prax. 25, 388-392. 